Article

\title{
Drought Stress Alleviation by ACC Deaminase Producing Achromobacter xylosoxidans and Enterobacter cloacae, with and without Timber Waste Biochar in Maize
}

\author{
Subhan Danish ${ }^{1}$, Muhammad Zafar-ul-Hye ${ }^{1, *}$, Shah Fahad ${ }^{2,3, *}$, Shah Saud ${ }^{4}$, \\ Martin Brtnicky ${ }^{5,6,7}$, Tereza Hammerschmiedt ${ }^{5,6}$ (D) and Rahul Datta ${ }^{5, *(D)}$ \\ 1 Department of Soil Science, Faculty of Agricultural Sciences and Technology, Bahauddin Zakariya University \\ Multan, Punjab 60800, Pakistan; sd96850@gmail.com \\ 2 Hainan Key Laboratory for Sustaianble Utilization of Tropical Bioresource, College of Tropical Crops, \\ Hainan University, Haikou Hainan 570228, China \\ 3 Department of Agronomy, The University of Haripur, Haripur, Khyber Pakhtunkhwa 22620, Pakistan \\ 4 Department of Horticulture, Northeast Agriculture University, Harbin 150030, China; saudhort@gmail.com \\ 5 Department of Agrochemistry, Soil Science, Microbiology and Plant Nutrition, Faculty of AgriSciences, \\ Mendel University in Brno, Zemedelska 1, 61300 Brno, Czech Republic; martin.brtnicky@mendelu.cz (M.B.); \\ tereza.hammerschmiedt@mendelu.cz (T.H.) \\ 6 Department of Geology and Pedology, Faculty of Forestry and Wood Technology, Mendel University in Brno, \\ Zemedelska 3, 61300 Brno, Czech Republic \\ 7 Institute of Chemistry and Technology of Environmental Protection, Brno University of Technology, \\ Faculty of Chemistry, Purkynova 118, 62100 Brno, Czech Republic \\ * Correspondence: zafarulhyegondal@yahoo.com (M.Z.-u.-H.); shah.fahad@mail.hzau.edu.cn (S.F.); \\ rahulmedcure@gmail.com (R.D.); Tel.: +420-773-990-283 (R.D.)
}

Received: 4 July 2020; Accepted: 24 July 2020; Published: 4 August 2020

\begin{abstract}
The high consumption of water in industries, domestic areas and increasing earth temperature are major hurdles for the optimization of maize yield. Being the third most widely cultivated cereal crop, improvement in maize yield is a big challenge under the limited availability of irrigation. As the water requirement for maize cultivation is high, it is time to introduce technologies that can mitigate drought stress and are environmentally friendly. The inoculation of rhizobacteria with '1-aminocyclopropane-1-carboxylate deaminase' (ACCD) can play an imperative role in that regard by decreasing stress ethylene in plants. Biochar (BC) can also alleviate drought stress. Therefore, a field study was conducted, to examine the single and combined application of drought-tolerant plant-growth-promoting rhizobacteria (PGPRs) Achromobacter xylosoxidans and Enterobacter cloacae, with $15 \mathrm{Mg} \mathrm{ha}^{-1}$ of timber waste biochar (TWBC) at normal irrigation $=16$ irrigations, mild drought $=$ 14 irrigations and severe drought $=12$ irrigation for maize cultivation. A significant improvement in shoot dry weight ( $28 \%)$, 1000-grains weight (19\%), grain yield (27\%), concentrations of N (43\%), P (92\%) and $\mathrm{K}(71 \%)$ in grains, rate of photosynthesis $(33 \%)$, transpiration rate $(55 \%)$, stomatal conductance $(104 \%)$, chlorophyll A (33\%), chlorophyll B (62\%) and total chlorophyll (45\%) of maize was noted under drought stress where E. cloacae + TWBC was applied. Likewise, the application of A. xylosoxidans + TWBC also significantly enhanced the plant height $(24 \%)$ and cob length $(9 \%)$ of maize under drought stress. In conclusion, E. cloacae is more effective than A. xylosoxidans, with $15 \mathrm{Mg} \mathrm{ha}^{-1} \mathrm{TWBC}$ to increase maize yield under drought stress, due to the potential of higher '1-aminocyclopropane-1-carboxylate' (ACC)-deaminase synthesis, better nutrient solubilization and indole acetic acid (IAA) production.
\end{abstract}

Keywords: ACC deaminase; biochar; gas exchange attributes; maize; nutrients; yield 


\section{Introduction}

Changing climatic conditions and scarcity of water have made the situation adverse to the cultivation of crops [1,2]. Increasing temperature of the earth due to global warming is playing an important role in the expansion of drought area over cultivatable land [3]. Under drought stress, most of the plants are unable to uptake ample water, which is required for optimum growth [4]. This is why drought stress is considered as the most crucial abiotic stress among all stresses for plants [1,5]. The excessive use of inorganic fertilizers leads to an increased susceptibility to drought, whereas the use of organic fertilizers leads to the risk of xenobiotic contamination [6-9].

When plants are cultivated with a limited supply of water, they produce higher levels of stress, generating ethylene $[10,11]$. Server drought stress stimulates '1-aminocyclopropane-1-carboxylic acid', (ACC) an ethylene precursor, that increases ethylene accumulation in plants [12]. Low conductance of stomata, poor transpiration rate, less biological nitrogen fixation, inhibition of abscisic acid activity, less uptake of macronutrients and micronutrients, decrease in chlorophyll contents, low roots elongation, high electrolyte leakage and the evoking of physiological responses are some of the major drawbacks of drought besides higher ethylene accumulation in plants. Such adverse effects in plants caused a significant decrease in yield attributes [12-16]. Among different plants, maize is the third most cultivated cereal worldwide. The share of maize in cereal grains production is $62 \%$ [17]. A nutritional diet grain of maize is rich in starch and protein $(78$ and $10 \%)$, fiber $(8.5 \%)$, oil $(4.8 \%)$ and sugar $(3.1 \%)$, which also helped to decrease the cholesterol of human blood $[18,19]$. However, the cultivation of maize under drought stress can decrease yield (with the loss of 24 million tons $\mathrm{yr}^{-1}$ ) when compared to a well-watered production [20].

To overcome the problem of drought produced stress ethylene, such plant-growth-promoting rhizobacteria (PGPRs) were identified that were capable to secrete '1-aminocyclopropane-1-carboxylate deaminase' (ACCD) [5,21-25]. The polymeric ACCD enzyme is dependent on pyridoxal 5-phosphate (PLP) [26] that serve as a sink for ACC (ethylene precursor) [22]. The reduction in ACC by its deamination via ACCD resulted in less biosynthesis of ethylene that is an important and beneficial trait of ACCD, producing PGPRs for the cultivation of plants under stress environment [27].

In recent years, the use of an activated black carbon named biochar (BC) has also become a center of interest among scientists all over the world [28-31]. Research conducted on the Amazonian dark earth called terra preta provided the basis for the application of BC as a soil amendment $[29,32]$. On other soils, a higher cation exchange capacity [32,33], improved soil fertility status and high concentration of phosphorus and organic contents [32] were attributes of terra preta that captured the attention of scientists, supporting the use of BC as a soil amendment [30,34-37]. Biochar is produced by the process of pyrolysis, that is an effective carbon sequestration technique which can be used for recycling agricultural and industrial waste [38]. The application of BC in soil significantly enhanced the latter's water-holding ability, due to its high capacity for the sorption of water and nutrients [39]. It can thus be effective to mitigate drought stress [40-42].

A lot of work on the sole application of BC and drought-tolerant ACCD containing PGPRs has been done [43-50], but little investigation has been made regarding the cumulative use of drought-tolerant ACCD containing PGPR with timber waste biochar (TWBC) to alleviate the drought stress in maize. It is hypothesized that the use of drought-tolerant ACCD containing PGPR and TWBC may be an effective and environmentally friendly approach to mitigate drought stress in maize.

\section{Materials and Methods}

\subsection{PGPR Strains}

Two most effective drought-tolerant PGPRs were isolated from a maize rhizosphere with ACCD were taken from the Soil Microbiology and Biochemistry Laboratory, Department of Soil Science, Faculty of Agricultural Sciences and Technology, Bahauddin Zakariya University Multan, in Punjab, Pakistan. The strains were identified as Enterobacter cloacae and Achromobacter xylosoxidans, and were 
grown on a Dworkin and Foster (DF) minimal salt medium, by using $0.5 \mathrm{M}$ ACC as a nitrogen source. The inoculum of the desired PGPR was made by using DF media without agar [51].

\subsection{Characterization of PGPRs}

ACCD activity $($ E. cloacae $=402.1 \pm 27.29$, A. xylosoxidans $=381.17 \pm 11.69 \mu \mathrm{mol} \alpha$-ketobutyrate nmol $\mathrm{mg}^{-1}$ protein $\mathrm{h}^{-1}$ ) was determined by the method adopted by Honma et. al. and El-Tarabily et al. [26,52] The method adopted by Glickmann et al. [53] was used for indole acetic acid determination by using Salkowski reagent with (E. cloacae $=78.79 \pm 0.35$ and A. xylosoxidans $=61.19 \pm 0.14 \mu \mathrm{g} / \mathrm{mL}$ ), and without L-tryptophan $(E$. cloacae $=3.39 \pm 0.41$ and $A$. xylosoxidans $=5.52 \pm 0.79 \mu \mathrm{g} / \mathrm{mL}$ ) $[54,55]$ methods, were adopted for phosphorus (E. cloacae $=66.3 \pm 0.38$ and $A$. $x$ ylosoxidans $=77.4 \pm 0.98 \mu \mathrm{g} / \mathrm{mL}$ ) and potassium solubilizing activities (E. cloacae $=19.1 \pm 0.82$ and $A$. xylosoxidans $=24.5 \pm 0.42 \mu \mathrm{g} / \mathrm{mL}$ ).

\subsection{Timber-Waste Biochar}

Timber waste was collected from local timber market for the production of biochar (BC). First the collected timber waste was sun dried and then subjected to pyrolysis at $389^{\circ} \mathrm{C}$ for $80 \mathrm{~min}$ [49]. Finally, fine powder of biochar was collected by grinding and passing it through a $\leq 2 \mathrm{~mm}$ sieve. Biochar $\mathrm{pH}$ and EC were assessed by making 1:20 $w / v$ biochar to water ratio [49]. Nitric and perchloric acid mixture in 2:1 ratio were used for wet digestion of TWBC [56]. The yellow colour method was used for phosphorus $(\mathrm{P})$ determination on a spectrophotometer [57]. Potassium and sodium were determined on flamephotometer [58]. Nitrogen (N) analysis was done by $\mathrm{H}_{2} \mathrm{SO}_{4}$ digestion, followed by distillation on Kjeldahl's distillation apparatus [59]. Ash content and volatile matter were assessed according to the methodology described by Qayyum et al. (2012), samples were heated in a muffle furnace at $550{ }^{\circ} \mathrm{C}$ and $450{ }^{\circ} \mathrm{C}$, respectively [60]. The fixed carbon in TWBC was assessed using the equation given by Noor et al. [61]:

$$
\text { Fixed Carbon }(\%)=100-(\% \text { Volatile Matter }+\% \text { Ash Content })
$$

Physio-chemical characteristics of TWBC are provided in Table 1.

Table 1. Pre-experimental characteristics of timber waste biochar and soil.

\begin{tabular}{cccc}
\hline Biochar & Value & Soil & Value \\
\hline $\mathrm{pH}$ & 7.26 & Sand $(\%)$ & 60 \\
$\mathrm{EC}_{e}\left(\mathrm{dS} \mathrm{m}^{-1}\right)$ & 1.22 & Silt $(\%)$ & 30 \\
Volatile Matter $(\%)$ & 8.96 & Clay $(\%)$ & 10 \\
Ash Content $(\%)$ & 28.9 & Texture & Sandy Clay Loam \\
Fixed Carbon $(\%)$ & 62.1 & $\mathrm{pH}_{s}$ & 8.44 \\
Total N (\%) & 0.21 & $\mathrm{EC}_{e}\left(\mathrm{dS} \mathrm{m}^{-1}\right)$ & 3.84 \\
Total P $(\%)$ & 0.62 & Organic Matter $(\%)$ & 0.40 \\
Total K $(\%)$ & 1.61 & Extractable P $\left(\mu \mathrm{g} \mathrm{g}^{-1}\right)$ & 4.31 \\
Total Na $(\%)$ & 0.19 & Extractable K $\left(\mu \mathrm{g} \mathrm{g}^{-1}\right)$ & 110 \\
\hline
\end{tabular}

\subsection{Soil Characteristic}

The experiment was conducted in the research area of the Department of Soil Science, Bahauddin Zakariya University Multan. For the characterization of soil, sampling was done in a zig-zag manner. Six samples were collected from the field and a composite sample was prepared for analyses by mixing 6 samples in equal amount. Soil was then passed through a $\leq 2 \mathrm{~mm}$ sieve and analyzed for characterization [62]. Hydrometer method was adopted from Gee et al. [63] and Walkley et al. [64] for the determination of soil organic matter. Extractable soil phosphorus was determined by Olsen and Sommers [65] methodology. Nadeem et al.'s [58] method was adopted for the analysis of extractable soil potassium. Soil characteristics vary with land use [66-68]; they are given in Table 1. 


\subsection{Seeds Collection and Inoculation}

The seeds of maize (Kenzo Hybride-123) were purchased from the local market. Seed sterilization was done using sodium hypochlorite (5\%) and ethanol (95\%) [69]. Inoculation was done by taking $100 \mathrm{~g}$ sterilized seeds, $10 \mathrm{~mL}$ PGPR inoculum and $10 \%$ glucose solution [70]. However, top dressing was done with biochar. Biochar was sterilized at $121{ }^{\circ} \mathrm{C}$ for $20 \mathrm{~min}$ in an autoclave before inoculation of seeds [71]. For the control treatment, seeds were also top-dressed with TWBC, along with $10 \%$ sugar solution [72].

\subsection{Field Preparation, Nutrients and Biochar Application}

In the experimental field, the plot of $4 \mathrm{~m}$ width and $5 \mathrm{~m}$ length with an area of $20 \mathrm{~m}^{2}$ was created for each treatment. To provide macronutrients for maize cultivation $\mathrm{N}, \mathrm{P}_{2} \mathrm{O}_{5}$ and $\mathrm{K}_{2} \mathrm{O}$ were applied at the rate of 200:150:100 $\mathrm{kg} \mathrm{ha}^{-1}$, as recommended NPK fertilizer (RNPKF) respectively [73]. All P and K fertilizers were applied in a single dose at the time of sowing, while $\mathrm{N}$ was applied in 4 splits (1st $=5-6$ leaf stage, 2nd 8-10 leaf stage, 3rd 14-16 leaf stage and 4th tasseling stage). For the application of N, $\mathrm{P}$ and $\mathrm{K}$, fertilizers of urea, DAP and SOP were used. Timber waster BC was added at the rate of $0.75 \%$ $=15$ tons $\mathrm{ha}^{-1}$ selected as the best application rate in a previous pot experiment. The conversion was made by using the equation of:

$$
1 \%=20 \text { tons ha }^{-1}(\text { where } 1 \text { ton }=1000 \mathrm{UK} \mathrm{Kg})
$$

\subsection{Seeds Sowing, Drought Stress and Treatment Plan}

In each plot, seeds of maize were sown by hand. Sterilized gloves were used for the PGPR inoculated seeds to avoid any contamination. Sixteen irrigations were provided for control, as per "production technology of maize 2017", issued by Directorate of Agricultural Information Punjab [74]. Fourteen irrigations were provided to introduce mild drought stress condition (1st skipped at tasseling, 2nd at flowering) and severe drought stress condition was induced by providing 12 irrigations (1st skipped after the end of juvenile, 2nd at tasseling, 3rd at flowering and 4th at milking). Each irrigation was 3 inches per plot. All 6 treatments were applied at 3 levels of irrigation (16, 14 and 12I), with 3 replications each, following randomized complete block design (RCBD). The treatments were control (without TWBC and PGPR), E. cloacae, A. xylosoxidans, TWBC $\left(15 \mathrm{Mg} \mathrm{ha}^{-1}\right)$, E. cloacae + TWBC and A. xylosoxidans + TWBC. Drought levels were maintained in main plots, while treatments were randomized in subplots.

\subsection{Vegetative Harvest}

Vegetative harvesting was done after 45 days of sowing, from 4 random spots of each plot and was analysed for photosynthetic pigments, electrolyte leakage and nutrients concentration in the shoot.

\subsection{Yield Attributes}

The maize plants' cob length, grains weight $\mathrm{cob}^{-1}$, number of grains $\mathrm{cob}^{-1}$, grains yield, 1000-grains weight and biological yield were noted at the time of maturity (115 days after sowing).

\subsection{Nutrients Concentration in Grain and Shoot}

Leaves were digested with $\mathrm{H}_{2} \mathrm{SO}_{4}$ for the $\mathrm{N}$ analysis [57] on Kjeldahl's distillation apparatus [59]. Phosporous concentration of leaf was determine by yellow colour method, and absorbance was set at $420 \mathrm{~nm}$ [57]. Total $\mathrm{K}$ concentration in shoot and grains were analyzed after digestion with di-acid $\left(\mathrm{HNO}_{3}-\mathrm{HClO}_{4}\right)$ mixture. Finally, reading was noted on a flame photometer, as described by Nadeem et al. [58] 


\subsection{Gas Exchange Parameters}

Infra-Red Gas Analyzer (CI-340) was used for the determination of net transpiration rate, net photosynthetic rate and stomatal conductance [75].

\subsection{Chlorophyll Content and Electrolyte Leakage}

The Arnon et al.'s [76] methodology was used for the determination of chlorophyll. Fresh leaves were taken once at vegetative maturity i.e., 50 days old plants when chlorophyll contents are at maximum. Lutts et al.'s [77] method was followed for analyses of electrolyte leakage (EL).

\subsection{Statistical Analyses}

Statistical analysis was carried out using standard procedures followed by steel et al. [78] Two factorial ANOVA was applied to get interactive graphs using Statistic 8.1 and SPSS 20. Treatments were compared at $p \leq 0.05$ using Tukey's test.

\section{Result}

\subsection{Plant Height, Shoot Dry Weight and Electrolyte Leakage}

Main effect and interactive effects of treatments (T) and various sources of irrigation (I) differed significantly for plant height. However, the main effect of $\mathrm{T}$ and I remained significant, while their interaction $(\mathrm{T} \times \mathrm{I})$ did not differ significantly for shoot dry weight and electrolyte leakage (Table 2). At 16, 14 and 12I, the interaction of PGPRs $\times$ TWBC was ordinal and significant for plant height (Figure 1A-C). However, the interactive effect of PGPRs $\times$ TWBC did not differ significantly, but ordinal at 16, 14 and 12I, for shoot dry weight and electrolyte leakage.

Table 2. Effect of sole and co-application of E. cloacae and A. xylosoxidans and timber waste biochar (TWBC) on plant height, shoot dry weight and electrolyte leakage of maize.

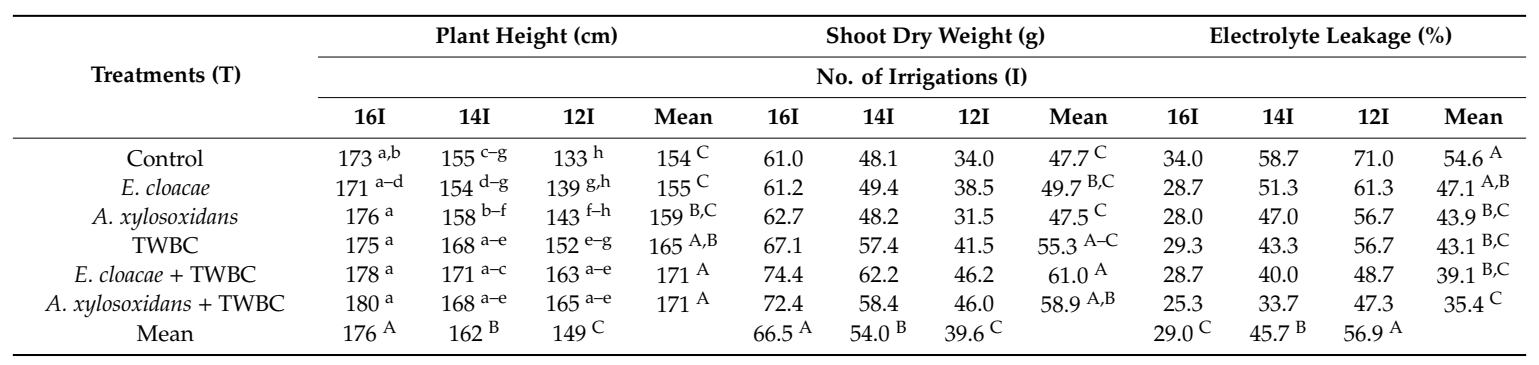

Small letters indicate interactive effect, while capital letters indicate main effect significance at $p \leq 0.05$. TWBC $=$

Timber waste biochar; I = Number of irrigations.

For plant height, all treatments did not differ significantly to each other at $16 \mathrm{I}$ and 14I. Application of treatments TWBC, A. xylosoxidans + TWBC and E. cloacae + TWBC differed significantly over control at 12I for plant height. Inoculation of $A$. xylosoxidans and E. cloacae with TWBC at 12I did not differ for plant height. Similarly, treatments A. xylosoxidans and E. cloacae did not differ significantly over control at 12I for plant height. However, A. xylosoxidans + TWBC and E. cloacae + TWBC treatments remained significant over A. xylosoxidans and E. cloacae treatments at 12I for plant height. The highest increase of $24 \%$ in plant height of maize was noted over control, where A. xylosoxidans + TWBC was applied as a treatment at 12I.

No significant increase or decrease in shoot dry weight was observed for treatments TWBC, A. xylosoxidans + TWBC and E. cloacae + TWBC, whereas a significant increase in shoot dry weight was noted in A. xylosoxidans + TWBC and E. cloacae + TWBC treatments, as compared to control. The highest increase of $28 \%$ in shoot dry weight was noted over the control in E. cloacae + TWBC treatment. 


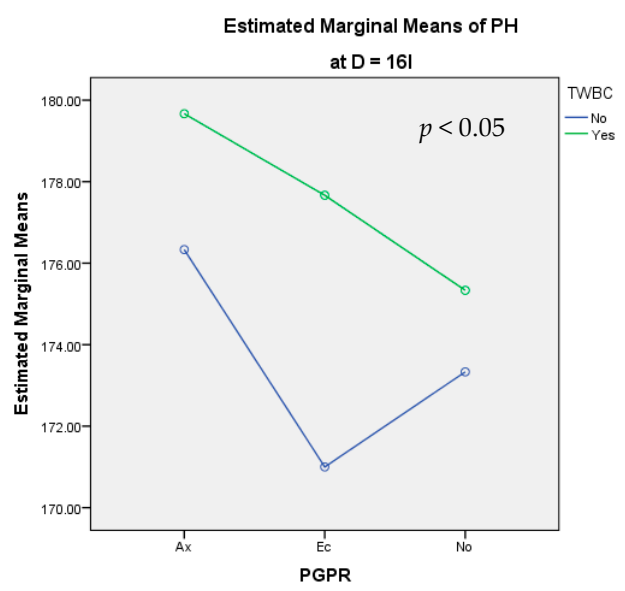

(A)

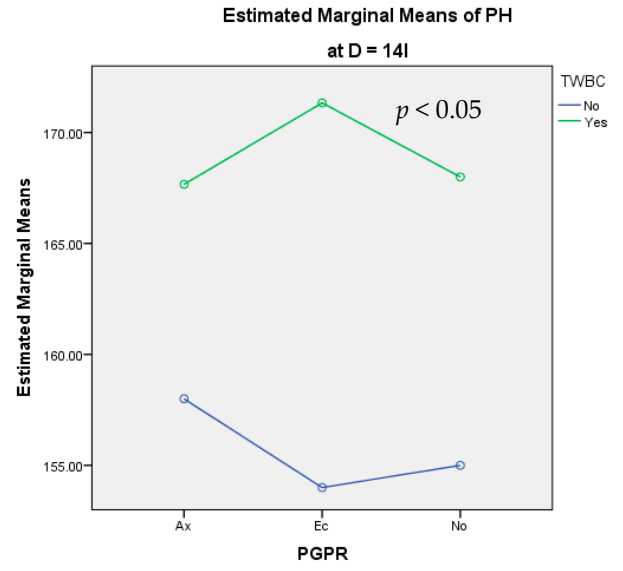

(B)

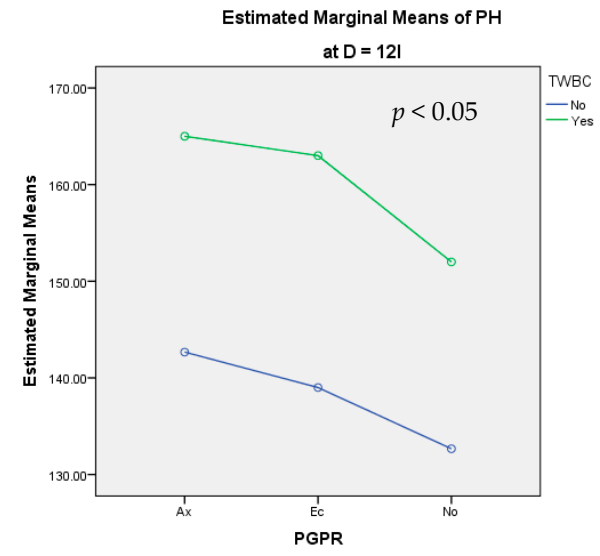

(C)

Figure 1. Interaction graph of plant-growth-promoting rhizobacteria (PGPR) and TWBC at 16 (A), 14 (B) and $12(\mathrm{C})$ number of irrigation (I) for maize plant height $(\mathrm{PH})$, where D represents drought levels. 
For electrolyte leakage, treatments A. xylosoxidans, TWBC, A. xylosoxidans + TWBC and E. cloacae + TWBC remained significant over control. Inoculation of $E$. cloacae as treatment was non-significant over control for electrolyte leakage. However, treatments A. xylosoxidans + TWBC and E. cloacae + TWBC also did not differ significantly over A. xylosoxidans and E. cloacae for electrolyte leakage. A significant reduction of $35 \%$ in electrolyte leakage was noted in A. xylosoxidans + TWBC treatment over control.

\subsection{Yield Attributes}

The main effects of $\mathrm{T}$ and I were significant for 1000 grains weight, grains yield and biological yield of maize (Table 3). Inoculation of PGPRs with TWBC gave ordinal interaction at 16, 14 and 12I, for 1000 grains weight, grain yield and biological yield. However, at 14I interaction of PGPRs and TWBC was disordinal for biological yield. Application of treatments E. cloacae + TWBC remained significant over control for 1000 grains weight. Treatments E. cloacae, A. xylosoxidans, TWBC and A. $x y$ losoxidans + TWBC were non-significant to each other and with control. The highest increase of 19\% in 1000 grains weight was noted over control, where E. cloacae + TWBC was applied.

Table 3. Effect of sole and co-application of E. cloacae and A. xylosoxidans and TWBC $\left(15 \mathrm{Mg} \mathrm{ha}^{-1}\right)$ on 1000 grains' weight, grains' yield and biological yield of maize.

\begin{tabular}{|c|c|c|c|c|c|c|c|c|c|c|c|c|}
\hline \multirow{3}{*}{ Treatments (T) } & \multicolumn{4}{|c|}{1000 Grains Weight (g) } & \multirow{2}{*}{\multicolumn{4}{|c|}{$\begin{array}{l}\text { Grain Yield (Mg ha }{ }^{-1} \text { ) } \\
\text { No. of Irrigations (I) }\end{array}$}} & \multicolumn{4}{|c|}{ Biological Yield (Mg ha $\left.{ }^{-1}\right)$} \\
\hline & \multicolumn{8}{|c|}{ No. of Irrigations (I) } & & & & \\
\hline & $16 \mathrm{I}$ & 14I & 12I & Mean & $16 I$ & 14I & $12 \mathrm{I}$ & Mean & $16 \mathrm{I}$ & 14I & 12I & Mean \\
\hline E. cloacae & 260.7 & 215.7 & 154.1 & $210.2^{\mathrm{A}, \mathrm{B}}$ & 3.40 & 3.05 & 2.30 & $2.92^{B}$ & 11.8 & 10.4 & 8.44 & $10.2^{\mathrm{C}}$ \\
\hline A. xylosoxidans & 240.6 & 194.1 & 155.2 & $196.6^{\text {В }}$ & 3.41 & 3.14 & 2.28 & $2.94^{\mathrm{B}}$ & 11.6 & 10.6 & 8.28 & $10.2^{C}$ \\
\hline TWBC & 266.7 & 217.0 & 184.3 & $222.7^{\mathrm{A}, \mathrm{B}}$ & 3.68 & 3.28 & 2.43 & $3.13^{\mathrm{A}, \mathrm{B}}$ & 13.2 & 11.7 & 8.88 & $11.2^{\mathrm{B}}$ \\
\hline E. cloacae + TWBC & 273.4 & 232.0 & 193.4 & $232.9^{\mathrm{A}}$ & 3.96 & 3.43 & 2.73 & $3.37^{\mathrm{A}}$ & 14.3 & 12.2 & 9.12 & $11.9^{\mathrm{A}, \mathrm{B}}$ \\
\hline
\end{tabular}

Capital letters indicate main effect significance at $p \leq 0.05$. TWBC $=$ Timber waste biochar; $\mathrm{I}=$ Number of irrigations.

For grain yield, treatments TWBC, E. cloacae + TWBC and A. xylosoxidans + TWBC remained non-significant to each other, but significant over control. Treatments E. cloacae + TWBC and A. xylosoxidans + TWBC remained significantly over E. cloacae and A. xylosoxidans, for improvement in grains yield. Inoculation of E. cloacae and A. xylosoxidans gave significant results over control for grains yield. The highest increase of $27 \%$ in grain yield was noted over control where E. cloacae + TWBC was applied.

For biological yield, application of E. cloacae + TWBC and A. xylosoxidans + TWBC treatments remained significant over control. Treatments E. cloacae + TWBC and TWBC did not differ significantly with each other, but $A$. xylosoxidans + TWBC was significant over TWBC for biological yield. Inoculation of E. cloacae and A. xylosoxidans treatments were non-significant over control for biological yield. Both E. cloacae + TWBC and A. xylosoxidans + TWBC treatments remained significant over E. cloacae and $A$. xylosoxidans treatments for biological yield. The highest increase of $30 \%$ in biological yield was noted over control where A. xylosoxidans + TWBC was applied.

\subsection{Cob Length, Number of Grains $\mathrm{Cob}^{-1}$ and Grains Weight $\mathrm{Cob}^{-1}$}

The main effect of $\mathrm{T}$ and I were significant for cob length, number of grains $\mathrm{cob}^{-1}$ and grains weight $\mathrm{cob}^{-1}$ of maize (Table 4). Ordinal interaction was observed between PGPRs with TWBC at 16, 14 and 12I for cob length, number of grains $\mathrm{cob}^{-1}$ and grains weight $\mathrm{cob}^{-1}$. For cob length, application of TWBC and A.xylosoxidans + TWBC remained significantly best over control. It was noted that E. cloacae + TWBC, A. xylosoxidans and E. cloacae were non-significant over control for cob length. The highest increase of $9 \%$ in cob length was noted over control, where A. xylosoxidans + TWBC was applied. 
Table 4. Effect of sole and co-application of E. cloacae and A. xylosoxidans and TWBC $\left(15 \mathrm{Mg} \mathrm{ha}^{-1}\right)$ on cob length, number of grains $\mathrm{cob}^{-1}$ and grains weight $\mathrm{cob}^{-1}$ of maize.

\begin{tabular}{|c|c|c|c|c|c|c|c|c|c|c|c|c|}
\hline \multirow{3}{*}{ Treatments (T) } & \multicolumn{4}{|c|}{ Cob Length (cm) } & \multirow{2}{*}{\multicolumn{4}{|c|}{$\begin{array}{c}\text { Number of Grains } \mathrm{Cob}^{-1} \\
\text { No. of Irrigations (I) }\end{array}$}} & \multicolumn{4}{|c|}{ Grains Weight $\mathrm{Cob}^{-1}$} \\
\hline & \multicolumn{8}{|c|}{ No. of Irrigations (I) } & & & & \\
\hline & $16 \mathrm{I}$ & $14 \mathrm{I}$ & $12 I$ & Mean & $16 \mathrm{I}$ & $14 I$ & $12 \mathrm{I}$ & Mean & $16 I$ & $14 \mathrm{I}$ & 12I & Mean \\
\hline Control & 16.5 & 14.0 & 12.8 & $14.5^{\mathrm{B}}$ & 349 & 307 & 265 & $307^{\mathrm{C}}$ & 85.2 & 59.0 & 38.5 & $60.9^{\mathrm{D}}$ \\
\hline E. cloacae & 17.0 & 15.1 & 13.7 & $15.2^{\mathrm{A}, \mathrm{B}}$ & 364 & 326 & 293 & $328^{\mathrm{B}}$ & 95.1 & 70.2 & 45.3 & $70.2^{\mathrm{C}, \mathrm{D}}$ \\
\hline A. xylosoxidans & 16.6 & 15.0 & 13.2 & $14.9^{\mathrm{A}, \mathrm{B}}$ & 377 & 323 & 272 & $324^{\mathrm{B}, \mathrm{C}}$ & 90.9 & 62.6 & 42.2 & $65.2^{\mathrm{D}}$ \\
\hline TWBC & 17.0 & 15.7 & 14.2 & $15.6^{\mathrm{A}}$ & 384 & 334 & 305 & $341^{\mathrm{B}}$ & 102.2 & 72.3 & 56.3 & $76.9^{B, C}$ \\
\hline E. cloacae + TWBC & 16.8 & 15.6 & 14.0 & $15.5^{\mathrm{A}, \mathrm{B}}$ & 404 & 375 & 340 & $373^{A}$ & 110.3 & 86.7 & 65.5 & $87.5^{\mathrm{A}}$ \\
\hline A. xylosoxidans + TWBC & 17.8 & 15.3 & 14.3 & $15.8^{\mathrm{A}}$ & 405 & 361 & 326 & $364^{\mathrm{A}}$ & 106.8 & 81.5 & 57.4 & $81.9^{\mathrm{A}, \mathrm{B}}$ \\
\hline Mean & $17.0^{\mathrm{A}}$ & $15.1^{\mathrm{B}}$ & $13.7^{\mathrm{C}}$ & & $381^{\mathrm{A}}$ & $338^{\mathrm{B}}$ & $300^{C}$ & & $98.4^{\mathrm{A}}$ & $72.1^{\mathrm{B}}$ & $50.9^{C}$ & \\
\hline
\end{tabular}

Capital letters show a significant difference of main effect at $p \leq 0.05$. TWBC $=$ Timber waste biochar; $\mathrm{I}=$ Number of irrigations.

For number of grains $\mathrm{cob}^{-1}$, A. xylosoxidans + TWBC and E. cloacae + TWBC performed significantly better over control. Application of treatments A. xylosoxidans + TWBC and E. cloacae + TWBC remained significant over TWBC, A. xylosoxidans and E. cloacae treatments for the number of grains $\mathrm{cob}^{-1}$. It was noted that $E$. cloacae and TWBC remained non-significant with each other but significant over control for number of grains $\mathrm{cob}^{-1}$. However, no significant difference was observed among control and A. xylosoxidans for number of grains $\mathrm{cob}^{-1}$. The highest increase of $21 \%$ in number of grains $\mathrm{cob}^{-1}$ was noted over control where E. cloacae + TWBC was applied.

For grains weight $\mathrm{cob}^{-1}$ application of A. xylosoxidans + TWBC and E. cloacae + TWBC treatments remained significant over control. Treatments A. xylosoxidans + TWBC did not differ significantly to TWBC, but E. cloacae + TWBC differed significantly over TWBC for improvement in grains weight $\mathrm{cob}^{-1}$. Inoculation of A. xylosoxidans and E. cloacae as treatments remained non-significant over control for grains weight $\mathrm{cob}^{-1}$. The highest increase of $44 \%$ in grains weight $\mathrm{cob}^{-1}$ was noted over control where E. cloacae + TWBC was applied.

\subsection{Grains Nutrients}

The main effect of $\mathrm{T}$ and I was significant for N, P and $\mathrm{K}$ concentration in maize grains (Table 5). Ordinal interaction was noted for PGPR $\times$ TWBC at 14 and 12I for N, P and K concentration in grains. For improvement in grain N concentration, treatments TWBC, A. xylosoxidans + TWBC and E. cloacae + TWBC were significant over control. No significant change was observed in grains $\mathrm{N}$ concentration where A. xylosoxidans and E. cloacae were inoculated as treatments over control. Inoculation of A. xylosoxidans and E. cloacae with TWBC remained significant over treatments $A$. xylosoxidans and E. cloacae, for improvement in grain $\mathrm{N}$ concentration. The highest increase of $43 \%$ in grains $\mathrm{N}$ concentration was noted over control, where E. cloacae + TWBC was applied.

Table 5. Effect of sole and co-application of E. cloacae and A. xylosoxidans and TWBC $\left(15 \mathrm{Mg} \mathrm{ha}^{-1}\right)$ on N,

$\mathrm{P}$ and $\mathrm{K}$ concentration in maize grains.

\begin{tabular}{|c|c|c|c|c|c|c|c|c|c|c|c|c|}
\hline \multirow{3}{*}{ Treatments $(\mathrm{T})$} & \multicolumn{4}{|c|}{ Grains Nitrogen (\%) } & \multicolumn{4}{|c|}{ Grains Phosphorus (\%) } & \multicolumn{4}{|c|}{ Grains Potassium (\%) } \\
\hline & \multicolumn{12}{|c|}{ No. of Irrigations (I) } \\
\hline & 16I & 14I & 12I & Mean & $16 \mathrm{I}$ & 14I & 12I & Mean & $16 \mathrm{I}$ & 14I & 12I & Mean \\
\hline Control & 1.64 & 1.36 & 0.90 & $1.30^{\mathrm{B}}$ & 0.16 & 0.11 & 0.09 & $0.12^{\mathrm{C}}$ & 0.95 & 0.67 & 0.36 & $0.66^{\mathrm{D}}$ \\
\hline E. cloacae & 1.73 & 1.41 & 1.14 & $1.43^{\mathrm{B}}$ & 0.22 & 0.16 & 0.12 & $0.17^{\mathrm{B}}$ & 1.07 & 0.87 & 0.64 & $0.86^{\mathrm{C}}$ \\
\hline A. xylosoxidans & 1.67 & 1.43 & 1.15 & $1.42^{\mathrm{B}}$ & 0.22 & 0.18 & 0.13 & $0.17^{\mathrm{B}}$ & 1.09 & 0.86 & 0.67 & $0.88^{\mathrm{B}, \mathrm{C}}$ \\
\hline TWBC & 2.03 & 1.64 & 1.35 & $1.68^{\mathrm{A}}$ & 0.25 & 0.19 & 0.14 & $0.19^{\mathrm{B}}$ & 1.22 & 0.95 & 0.76 & $0.98^{\mathrm{B}, \mathrm{C}}$ \\
\hline E. cloacae + TWBC & 2.16 & 1.82 & 1.59 & $1.86^{\mathrm{A}}$ & 0.28 & 0.23 & 0.18 & $0.23^{\mathrm{A}}$ & 1.30 & 1.15 & 0.94 & $1.13^{\mathrm{A}}$ \\
\hline A. xylosoxidans + TWBC & 2.13 & 1.67 & 1.43 & $1.75^{\mathrm{A}}$ & 0.25 & 0.20 & 0.15 & $0.20^{\mathrm{A}, \mathrm{B}}$ & 1.29 & 1.00 & 0.75 & $1.01^{\mathrm{A}, \mathrm{B}}$ \\
\hline Mean & $1.89^{\mathrm{A}}$ & $1.56^{\mathrm{B}}$ & $1.26^{\mathrm{C}}$ & & $0.23^{\mathrm{A}}$ & $0.18^{\mathrm{B}}$ & $0.14^{\mathrm{C}}$ & & $1.15^{\mathrm{A}}$ & $0.92^{\mathrm{B}}$ & $0.68^{C}$ & \\
\hline
\end{tabular}

Capital letters show a significant difference of main effect at $p \leq 0.05$. TWBC $=$ Timber waste biochar; $\mathrm{I}=$ Number of irrigations.

For grains P concentration, treatments A. xylosoxidans + TWBC and E. cloacae + TWBC remained significant over control. Treatment A. xylosoxidans + TWBC was non-significant over TWBC, 
A. xylosoxidans and E. cloacae treatments for grains P concentration. Treatments TWBC, A. xylosoxidans and E. cloacae were significant over control for grains $P$ concentration. Inoculation of E. cloacae with TWBC also remained significant, as compared to E. cloacae treatment for grains $\mathrm{P}$ concentration. The highest increase of $92 \%$ in grains P concentration was noted over control where E. cloacae + TWBC was applied.

For grains K concentration, treatments A. xylosoxidans + TWBC and E. cloacae + TWBC were significant over control. Application of A.xylosoxidans + TWBC was non-significant over TWBC and A. xylosoxidans treatments for grains $\mathrm{K}$ concentration. Inoculation of E. cloacae with TWBC remained significant, as compared to E. cloacae, for grains K concentration. Treatment TWBC, A. xylosoxidans and E. cloacae were significantly different over control for grains $\mathrm{K}$ concentration. The highest increase of $71 \%$ in grains K concentration was noted in E. cloacae + TWBC treatment over control.

\subsection{Shoot Nutrients}

The main effect of $\mathrm{T}$ and I was significant for nitrogen $(\mathrm{N})$, phosphorus $(\mathrm{P})$ and potassium $(\mathrm{K})$ concentration in the shoot of maize (Table 6). Two factorial ANOVA showed that PGPRs $\times$ TWBC at 16,14 and 12I was ordinal for $\mathrm{N}$ and $\mathrm{K}$ concentration in maize shoot. However, for $\mathrm{P}$ concentration in maize shoot, PGPRs $\times$ TWBC was disordinal at 16, 14 and 12I.

Table 6. Effect of sole and co-application of E. cloacae and A. xylosoxidans and TWBC $\left(15 \mathrm{Mg} \mathrm{ha}^{-1}\right)$ on N, $\mathrm{P}$ and $\mathrm{K}$ concentration in maize shoot.

\begin{tabular}{|c|c|c|c|c|c|c|c|c|c|c|c|c|}
\hline \multirow{3}{*}{ Treatments (T) } & \multicolumn{4}{|c|}{ Shoot Nitrogen (\%) } & \multicolumn{4}{|c|}{ Shoot Phosphorus (\%) } & \multicolumn{4}{|c|}{ Shoot Potassium (\%) } \\
\hline & \multicolumn{12}{|c|}{ No. of Irrigations (I) } \\
\hline & 16I & 14I & $12 I$ & Mean & $16 I$ & $14 \mathrm{I}$ & $12 \mathrm{I}$ & Mean & 16I & 14I & 12I & Mean \\
\hline E. cloacae & 1.93 & 1.71 & 1.24 & $1.63^{\mathrm{C}, \mathrm{D}}$ & 0.24 & 0.21 & 0.16 & $0.21^{C}$ & 1.17 & 1.03 & 0.65 & $0.95^{\mathrm{B}}$ \\
\hline A. xylosoxidans & 1.80 & 1.55 & 1.23 & $1.53^{\mathrm{C}, \mathrm{D}}$ & 0.24 & 0.20 & 0.16 & $0.20^{C}$ & 1.14 & 0.96 & 0.72 & $0.94^{\mathrm{B}}$ \\
\hline TWBC & 2.08 & 1.72 & 1.36 & $1.72^{\mathrm{B}, \mathrm{C}}$ & 0.26 & 0.21 & 0.17 & $0.22^{\mathrm{B}, \mathrm{C}}$ & 1.32 & 1.14 & 0.84 & $1.10^{\mathrm{A}, \mathrm{B}}$ \\
\hline Mean & $2.07^{\mathrm{A}}$ & $1.76^{\mathrm{B}}$ & $1.32^{\mathrm{C}}$ & & $0.26^{\mathrm{A}}$ & $0.22^{\mathrm{B}}$ & $0.17^{\mathrm{C}}$ & & $1.25^{\mathrm{A}}$ & $1.07^{\mathrm{B}}$ & $0.77^{\mathrm{C}}$ & \\
\hline
\end{tabular}

Capital letters show a significant difference of main effect at $p \leq 0.05$. TWBC $=$ Timber waste biochar; $\mathrm{I}=$ Number of irrigations.

For N and P concentration, treatments A. xylosoxidans + TWBC and E. cloacae + TWBC were significant over control. Application of A. xylosoxidans + TWBC and TWBC were non-significant with each other for $\mathrm{N}$ and $\mathrm{P}$ concentration in the shoot. Inoculation of $A$. xylosoxidans and E. cloacae also remained non-significantly over TWBC for $\mathrm{N}$ and $\mathrm{P}$ concentration in the shoot. No significant difference was noted among A. xylosoxidans, E. cloacae and control for $\mathrm{N}$ concentration in the shoot. However, for $\mathrm{P}$ concentration in shoot inoculation of $A$. xylosoxidans and E. cloacae as treatments remained significant over control. Both A. xylosoxidans + TWBC and E. cloacae + TWBC were significant over A. xylosoxidans and E. cloacae for $\mathrm{N}$ and $\mathrm{P}$ concentration in the shoot. The highest increase of 45 and $73 \%$ was noted in $\mathrm{N}$ and $\mathrm{P}$ concentration in shoot respectively, over control in E. cloacae $+\mathrm{BC}$.

For K concentration in the shoot, TWBC, A. xylosoxidans + TWBC and E. cloacae + TWBC were significant over control. Inoculation of $A$. xylosoxidans and E. cloacae remained non-significant to TWBC for $\mathrm{K}$ concentration in the shoot. However, for $\mathrm{K}$, concentration in shoot treatments $A$. xylosoxidans and E. cloacae remained significant over control. It was observed that $A$. xylosoxidans + TWBC and E. cloacae + TWBC remained significantly better over A. xylosoxidans and E. cloacae for $\mathrm{K}$ concentration in the shoot. The highest increase of $71 \%$ in $\mathrm{K}$ concentration was noted over control, where A. xylosoxidans + TWBC was applied.

\subsection{Gas Exchange Attributes}

The main effect of $\mathrm{T}$ and I was significant for photosynthetic rate, respiration rate and stomatal conductance of maize (Table 7). An ordinal interaction was found at 16I for TWBC and PGPRs, 
but disordinal at 14 and 12I for photosynthetic rate in maize. In case of transpiration rate, interaction of PGPRs and TWBC were ordinal at 14 and 12I, but disordinal at 16I. However, at 16, 14 and 12I, TWBC and PGPRs interaction was ordinal for stomatal conductance in maize.

Table 7. Effect of sole and co-application of E. cloacae and A. xylosoxidans and TWBC $\left(15 \mathrm{Mg} \mathrm{ha}^{-1}\right)$ on gas exchange attributes of maize.

\begin{tabular}{|c|c|c|c|c|c|c|c|c|c|c|c|c|}
\hline \multirow{3}{*}{ Treatments (T) } & \multicolumn{4}{|c|}{ Photosynthetic Rate $\left(\mu \mathrm{mol} \mathrm{m}{ }^{-1} \mathrm{~s}^{-1}\right)$} & \multicolumn{4}{|c|}{ Transpiration Rate $\left(\mathrm{mmol} \mathrm{m}^{-1} \mathrm{~s}^{-1}\right)$} & \multicolumn{4}{|c|}{ Stomatal Conductance $\left(\mu \mathrm{mol} \mathrm{m}{ }^{-1} \mathrm{~s}^{-1}\right)$} \\
\hline & \multicolumn{12}{|c|}{ No. of Irrigations (I) } \\
\hline & 16I & 14I & 12I & Mean & $16 I$ & 14I & 12I & Mean & $16 I$ & 14I & 12I & Mean \\
\hline E. cloacae & 22.7 & 19.4 & 16.9 & $19.7^{\mathrm{B}, \mathrm{C}}$ & 3.70 & 2.87 & 2.00 & $2.86^{\mathrm{B}, \mathrm{C}}$ & 0.27 & 0.20 & 0.14 & $0.21^{\mathrm{C}}$ \\
\hline A. xylosoxidans & 22.1 & 18.7 & 14.2 & $18.3^{\mathrm{C}}$ & 3.43 & 2.80 & 2.03 & $2.76^{\mathrm{B}, \mathrm{C}}$ & 0.28 & 0.21 & 0.17 & $0.22^{C}$ \\
\hline TWBC & 25.5 & 22.0 & 17.0 & $21.5^{\mathrm{A}, \mathrm{B}}$ & 4.03 & 3.10 & 2.20 & $3.11^{\mathrm{B}, \mathrm{C}}$ & 0.39 & 0.28 & 0.22 & $0.30^{B}$ \\
\hline Mean & $25.0^{\mathrm{A}}$ & $20.9^{B}$ & $16.5^{\mathrm{C}}$ & & $3.89^{\mathrm{A}}$ & $3.08^{B}$ & $2.24^{\mathrm{C}}$ & & $0.35^{\mathrm{A}}$ & $0.26^{\mathrm{B}}$ & $0.20^{\mathrm{C}}$ & \\
\hline
\end{tabular}

Capital letters show a significant difference of main effect at $p \leq 0.05$. TWBC $=$ Timber waste biochar; $\mathrm{I}=$ Number of irrigations.

For photosynthetic rate, treatments TWBC, A. xylosoxidans + TWBC and E. cloacae + TWBC remained significant over control. It was noted that treatments $E$. cloacae and TWBC were non-significant to each other for photosynthetic rate. Inoculation of $A$. xylosoxidans and E. cloacae as treatments did not differ significantly over control for photosynthetic rate. However, A. xylosoxidans + TWBC and E. cloacae + TWBC as treatments remained significant over A. xylosoxidans and E. cloacae for photosynthetic rate. The highest increase of $33 \%$ in photosynthetic rate was noted over control where E. cloacae + TWBC was applied.

For transpiration rate, A. xylosoxidans + TWBC and E. cloacae + TWBC were significant over control for transpiration rate. Treatments E. cloacae, A. xylosoxidans and TWBC were non-significant over control for transpiration rate. However, E. cloacae + TWBC differed significantly over E. cloacae and TWBC for transpiration rate. The highest increase of $55 \%$ in transpiration rate was noted over control where E. cloacae + TWBC was applied.

Application of A. xylosoxidans + TWBC and E. cloacae + TWBC were significant over control for stomatal conductance. It was observed that $A$. xylosoxidans + TWBC and TWBC were non-significant to each other for stomatal conductance. Inoculation of $E$. cloacae and A. xylosoxidans did not differ significantly over control for stomatal conductance. However, E. cloacae + TWBC remained significant over E. cloacae and TWBC for stomatal conductance. The highest increase of $104 \%$ was noted over control where E. cloacae + TWBC was applied.

\subsection{Chlorophyll Contents}

The main effect of $\mathrm{T}$ and I differs significantly for chlorophyll $\mathrm{a}$, chlorophyll $\mathrm{b}$ and total chlorophyll of maize (Table 8). Inoculation of PGPRs and TWBC showed ordinal interaction at 16I and 12I, but disordinal at 14I for chlorophyll a and $b$. For total chlorophyll, TWBC $\times$ PGPRs remained ordinal at 16I, but disordinal at 14 and 12I.

Application of treatments A. xylosoxidans + TWBC and E. cloacae + TWBC remained significant over control for chlorophyll a content. E. cloacae + TWBC and A. xylosoxidans + TWBC remained significant over E. cloacae and A.xylosoxidans for chlorophyll a. Both TWBC and A. xylosoxidans + TWBC for chlorophyll a content. Similarly, TWBC and E. cloacae treatments remained non-significant with each other for chlorophyll a content. Inoculation of $E$. cloacae and TWBC remained significant over control for chlorophyll a. However, inoculation of A. xylosoxidans was non-significant over control for chlorophyll a content. Highest increase of $33 \%$ in chlorophyll a content was noted over control where E. cloacae + TWBC was applied. 
Table 8. Effect of sole and co-application of E. cloacae and A. xylosoxidans and TWBC $\left(15 \mathrm{Mg} \mathrm{ha}^{-1}\right)$ on chlorophyll contents of maize.

\begin{tabular}{|c|c|c|c|c|c|c|c|c|c|c|c|c|}
\hline \multirow{3}{*}{ Treatments (T) } & \multicolumn{4}{|c|}{ Chlorophyll a (mg g $\left.{ }^{-1}\right)$} & \multirow{2}{*}{\multicolumn{4}{|c|}{$\begin{array}{c}\text { Chlorophyll b }\left(\mathrm{mg} \mathrm{g}^{-1} \text { ) }\right. \\
\text { No. of Irrigations (I) }\end{array}$}} & \multicolumn{4}{|c|}{ Total Chlorophyll (mg g $\left.\mathrm{g}^{-1}\right)$} \\
\hline & & & & & & & & & & & & \\
\hline & $16 I$ & $14 \mathrm{I}$ & $12 I$ & Mean & $16 I$ & 14I & 12I & Mean & $16 I$ & 14I & $12 \mathrm{I}$ & Mean \\
\hline Control & 0.65 & 0.56 & 0.43 & $0.55^{\mathrm{E}}$ & 0.44 & 0.35 & 0.24 & $0.34^{\mathrm{D}}$ & 1.08 & 0.91 & 0.67 & $0.89^{\mathrm{D}}$ \\
\hline E. cloacae & 0.71 & 0.61 & 0.52 & $\begin{array}{l}0.61 \\
\mathrm{C}, \mathrm{D}\end{array}$ & 0.52 & 0.43 & 0.29 & $0.42^{\mathrm{C}}$ & 1.23 & 1.05 & 0.81 & $1.03^{\mathrm{C}}$ \\
\hline A. xylosoxidans & 0.71 & 0.57 & 0.50 & $0.59^{\mathrm{D}, \mathrm{E}}$ & 0.50 & 0.43 & 0.29 & $0.41^{\mathrm{C}}$ & 1.22 & 1.00 & 0.79 & $1.00^{\mathrm{C}}$ \\
\hline TWBC & 0.78 & 0.66 & 0.55 & $0.66^{\mathrm{B}, \mathrm{C}}$ & 0.56 & 0.48 & 0.39 & $0.48^{\mathrm{B}}$ & 1.34 & 1.15 & 0.94 & $1.14^{\mathrm{B}}$ \\
\hline E. cloacae + TWBC & 0.84 & 0.73 & 0.62 & $0.73^{\mathrm{A}}$ & 0.64 & 0.56 & 0.46 & $0.55^{\mathrm{A}}$ & 1.49 & 1.29 & 1.08 & $1.29^{\mathrm{A}}$ \\
\hline A. xylosoxidans + TWBC & 0.81 & 0.70 & 0.63 & $0.71^{\mathrm{A}, \mathrm{B}}$ & 0.60 & 0.53 & 0.41 & $0.51 \mathrm{~A}, \mathrm{~B}$ & 1.41 & 1.24 & 1.04 & $1.23^{\mathrm{A}}$ \\
\hline Mean & $0.75^{\mathrm{A}}$ & $0.64^{\mathrm{B}}$ & $0.54^{C}$ & & $0.54^{\mathrm{A}}$ & $0.46^{\mathrm{B}}$ & $0.35^{\mathrm{C}}$ & & $1.29^{\mathrm{A}}$ & $1.10^{\mathrm{B}}$ & $0.89^{C}$ & \\
\hline
\end{tabular}

Capital letters shows a significant difference of main effect at $p \leq 0.05$. TWBC $=$ Timber waste biochar; $\mathrm{I}=$ Number of irrigations.

For chlorophyll b, treatments A. xylosoxidans + TWBC and E. cloacae + TWBC were significant over control. Application of TWBC remained non-significant with A. xylosoxidans + TWBC for chlorophyll b content. Treatments with E. cloacae + TWBC were significant over TWBC and E. cloacae treatments for chlorophyll b. Similarly, A. xylosoxidans + TWBC was significant over A. xylosoxidans treatment. It was noted that $E$. cloacae and $A$. xylosoxidans as treatments did not differ significantly to each other, but differ significantly over control for chlorophyll $\mathrm{b}$ content. Highest increase of $62 \%$ in chlorophyll $b$ content was noted over control in E. cloacae + TWBC treatment.

For total chlorophyll, A. xylosoxidans + TWBC and E. cloacae + TWBC treatments were statistically similar to each other, but differ significantly over control. Both A. xylosoxidans + TWBC and E. cloacae + TWBC treatments remained significantly better over TWBC, A. xylosoxidans and E. cloacae treatments for total chlorophyll. Inoculation of $A$. xylosoxidans and E. cloacae did not differ significantly with each other, but differ significantly over control for total chlorophyll content. Highest increase of $45 \%$ in total chlorophyll content was noted over control where E. cloacae + TWBC was applied.

\section{Discussion}

In the current study, the application of drought tolerent ACC-deaminase containing PGPRs i.e., E. cloacae and A. xylosoxidans with TWBC, significantly enhanced maize growth, photosynthetic pigments, nutrients in shoot and grains cultivated under various levels of irrigation (16I, 14I and 12I). Under severe drought stress, co-application of ACC-deaminase containing PGPRs E. cloacae and A. xylosoxidans with $15 \mathrm{Mg} \mathrm{ha}^{-1}$ TWBC produced significantly better results as compared to sole inoculation of E. cloacae and A. xylosoxidans treatments with respect to plant height and shoot dry weight of maize. Better PGPR colonization, ACCD activity and improvement in water holding capacity by co-application of PGPRs and TWBC might be responsible for improvement in plant height and shoot dry weight of maize. Application of TWBC with PGPRs in the current study significantly enhanced photosynthetic rate, transpiration rate and stomatal conductance, especially at 14I and 12I. This improvement in photosynthetic rate, transpiration rate and stomatal conductance might be due to the high water holding capacity (WHC) of TWBC and reduction of ethylene biosysnthesis.

Mayak et al. [79] suggested that the upregulation of ACC from root to shoot under drought stress and limited availibility of nutrients enhances the synthesis of stress ethylene in root and shoot of plants. Glick et al. [80] proposed that the synthesis of indole acetic acid (IAA) by PGPR stimulates ACC synthase enzyme that converts S-adenosylmethionine to ACC. Plants, roots and seeds exude accumulated stress ethylene in rhizosphere, which is cleaved into $\mathrm{NH}_{3}$ and $\alpha$-ketobutyrate by PGPRs secreted ACCD. Reduction in ethylene due to its cleavage resulted in the better elongation of roots. This improvement in root elongation facilitates plant to uptake water and nutrients by increasing rhizosphere area [81]. In addition to the above, higher surface area and pore spaces are such characteristics that make biochar an effective soil amendment for improvement in the bioavailibility of water to plants under drought stress [40,82-84]. 
A significant improvement in plant height signified the imperative role of co-application of E. cloacae and A. xylosoxidans with TWBC over sole application of TWBC and control. Roots secrete organic acids, sugars, vitamins, phytosiderophores, nucleosides amino acids and mucilage, that attract PGPRs and resulted in better colonization of PGPRs, uptake of water and nutrients [85-87]. However, it is well documented that the colonization of PGPR is also improved when PGPR are inoculated with biochar [47]. In current study inoculation of E. cloacae and A. xylosoxidans TWBC significantly decreased electrolyte leakage over control is another solid evidence of less ethylene accumulation under drought stress. The findings of Nadeem et al. (2017) in cucumber under drought stress justified our results regarding less electrolyte leakage when they applied PGPRs and biochar cumulatively [88]. Matile et al. [89] suggested that cell membrane mostly loses its integrity by the degradation of lipid molecules as a result of higher accumulation of ethylene. Direct contact of ethylene with chloroplast by degradation of lipids in cell membrane activates chlorophyllase (chlase) gene that severely damaged chlorophyll [89].

A significant improvement in chlorophyll pigments synthesis at $14 \mathrm{I}$ and $12 \mathrm{I}$ is in agreement with low ethylene accumulation due to deamination of ACC and improvement in soil water holding capacity by TWBC. According to Zheng et al. [90] and Borch et al. [91], the limited availability of $\mathrm{N}$ and $\mathrm{P}$ is an allied factor that significantly contributes to higher biosynthesis and accumulation of ethylene. The improvement in shoot P (E. cloacae and A. xylosoxidans) and K (E. cloacae + TWBC and A. xylosoxidans + TWBC) concentration at 14I and 12I signified an imperative effect of PGPR and TWBC for significant improvement in the yield attributes (1000-grains weight, grains yield and biological yield) of maize plants. Younis et al. 2014 also noted similar results for the improvement in the uptake of nutrients concentration by the addition of cotton sticks biochar [92]. Richardson et al. [93] found a significant increase in the fresh and dry weight of plants by the better uptake of P. Application of biochar significantly increased the uptake of $\mathrm{P}$ in the plants [50]. According to Chan et al. [94], a significant increase in the bioavailability of $\mathrm{N}$ is due to improvement in the soil cation exchange capacity when biochar is applied as an amendment. In the current study, better uptake of $\mathrm{K}$ in maize at 14I and 12I by co-application of PGPR and TWBC might be another allied factor responsible for the mitigation of drought stress.

\section{Conclusions}

From the results, it is concluded that the application of TWBC with E. cloacae and A. xylosoxidans is a better approach for promotion of growth, gas exchange attributes, nutrients concentration in shoot and grains and yield in maize under drought stress. However, combined application of PGPR E. cloacae is more effective than A. xylosoxidans with $15 \mathrm{Mg} \mathrm{ha}^{-1} \mathrm{TWBC}$, to mitigate drought stress in maize.

Author Contributions: Conceptualization, M.Z.-u.-H.; methodology, M.Z.-u.-H.; software, R.D. and S.D.; validation, S.D. and M.B.; formal analysis, S.D.; investigation, S.D.; resources, M.Z.-u.-H.; data curation, S.S.; writing - original draft preparation, S.D.; writing—review and editing, R.D., T.H. and S.F.; visualization, M.Z.-u.-H.; supervision, M.Z.-u.-H. All authors have read and agreed to the published version of the manuscript.

Funding: The first author is grateful to Higher Education Commission (HEC) of Pakistan to provide Indigenous Scholarship (PIN: 315-8403-2AV3-049) for his PhD study in Pakistan. The work was also supported by the project of Technology Agency of the Czech Republic TH03030319.

Acknowledgments: The paper is part of the first author's PhD Dissertation Chapter 8, submitted to HEC 04-September-2019.

Conflicts of Interest: The authors declare no conflict of interest.

\section{References}

1. Anjum, S.A.; Wang, L.C.; Farooq, M.; Hussain, M.; Xue, L.L.; Zou, C.M. Brassinolide application improv. the drought tolerance in maize through modulation of enzymatic antioxidants and leaf gas exchange. J. Agron. Crop Sci. 2011, 197, 177-185. [CrossRef] 
2. Datta, R.; Kelkar, A.; Baraniya, D.; Molaei, A.; Moulick, A.; Meena, R.S.; Formanek, P. Enzymatic degradation of lignin in soil: A review. Sustainability 2017, 9, 1163. [CrossRef]

3. Mir, R.R.; Zaman-Allah, M.; Sreenivasulu, N.; Trethowan, R.; Varshney, R.K. Integrated genomics, physiology and breeding approaches for improving drought tolerance in crops. Theor. Appl. Genet. 2012, 125, 625-645. [CrossRef] [PubMed]

4. Manivannan, P.; Jaleel, C.A.; Somasundaram, R.; Panneerselvam, R. Osmoregulation and antioxidant metabolism in drought-stressed Helianthus annuus under triadimefon drenching. Comptes Rendus Biol. 2008, 331, 418-425. [CrossRef]

5. Danish, S.; Zafar-ul-Hye, M.; Hussain, M.; Shaaban, M.; Núñez-delgado, A. Rhizobacteria with ACC-deaminase activity improve nutrient uptake, chlorophyll contents and early seedling growth of wheat under PEG- induced osmotic stress. Int. J. Agric. Biol. 2019, 21, 1212-1220. [CrossRef]

6. Brtnicky, M.; Dokulilova, T.; Holatko, J.; Pecina, V.; Kintl, A.; Latal, O.; Vyhnanek, T.; Prichystalova, J.; Datta, R. Long-term effects of biochar-based organic amendments on soil microbial parameters. Agronomy 2019, 9, 747. [CrossRef]

7. Molaei, A.; Lakzian, A.; Haghnia, G.; Astaraei, A.; Rasouli-Sadaghiani, M.; Teresa Ceccherini, M.; Datta, R. Assessment of some cultural experimental methods to study the effects of antibiotics on microbial activities in a soil: An incubation study. PLoS ONE 2017, 12, e0180663. [CrossRef]

8. Meena, R.S.; Kumar, S.; Datta, R.; Lal, R.; Vijayakumar, V.; Brtnicky, M.; Sharma, M.P.; Yadav, G.S.; Jhariya, M.K.; Jangir, C.K. Impact of agrochemicals on soil microbiota and management: A review. Land 2020, 9, 34. [CrossRef]

9. Molaei, A.; Lakzian, A.; Datta, R.; Haghnia, G.; Astaraei, A.; Rasouli-Sadaghiani, M.; Ceccherini, M.T. Impact of chlortetracycline and sulfapyridine antibiotics on soil enzyme activities. Int. Agrophysics 2017, 31, 499. [CrossRef]

10. Mayak, S.; Tirosh, T.; Glick, B.R. Plant growth-promoting bacteria that confer resistance to water stress in tomatoes and peppers. Plant Sci. 2004, 166, 525-530. [CrossRef]

11. Gamalero, E.; Glick, B.R. Bacterial modulation of plant ethylene levels. Plant Physiol. 2015, 169. [CrossRef] [PubMed]

12. Wang, W.; Vinocur, B.; Altman, A. Plant responses to drought, salinity and extreme temperatures: Towards genetic engineering for stress tolerance. Planta 2003, 218, 1-14. [CrossRef] [PubMed]

13. Tanaka, Y.; Sano, T.; Tamaoki, M.; Nakajima, N.; Kondo, N.; Hasezawa, S. Ethylene inhibits abscisic acid-induced stomatal closure in Arabidopsis. Plant Physiol. 2005, 138, 2337-2343. [CrossRef] [PubMed]

14. Tamimi, S.M.; Timko, M.P. Effects of ethylene and inhibitors of ethylene synthesis and action on nodulation in common bean (Phaseolus vulgaris L.). Plant Soil 2003, 257, 125-131. [CrossRef]

15. Danish, S.; Zafar-ul-Hye, M. Co-application of ACC-deaminase producing PGPR and timber-waste biochar improves pigments formation, growth and yield of wheat under drought stress. Sci. Rep. 2019, 9, 5999. [CrossRef]

16. Zafar-ul-Hye, M.; Danish, S.; Abbas, M.; Ahmad, M.; Munir, T.M. ACC deaminase producing PGPR Bacillus amyloliquefaciens and agrobacterium fabrum along with biochar improve wheat productivity under drought stress. Agronomy 2019, 9, 343. [CrossRef]

17. Farhad, W.; Cheema, M.; Saleem, M.; Saqib, M. Evaluation of drought tolerance in maize hybrids. Int. J. Agric. Biol. 2011, 13, 523-528.

18. Chaudhry, A. Agronomy in "Maize in Pakistan" Punjab Agriculture Coordination board Univ; University of Agriculture Faisalabad: Faisalabad, Pakistan, 1983.

19. Chaudhary, D.P.; Kumar, S.; Yadav, O.P. Nutritive value of maize: Improvements, applications and constraints. In Maize: Nutrition Dynamics and Novel Uses; Springer India: New Delhi, India, 2014; pp. 3-17.

20. Edmeades, G.O.; Bolanos, J.; Hernandez, M.; Bello, S. Causes for silk delay in a lowland tropical maize population. Crop Sci. 1993, 33, 1029-1035. [CrossRef]

21. Shahzad, S.M.; Khalid, A.; Arshad, M. Kalil-ur-Rehman Screening rhizobacteria containing ACC-deaminase for growth promotion of wheat under water stress. Pak. J. Bot. 2013, 45, 91-96.

22. Shah, S.; Li, J.; Moffatt, B.A.; Glick, B.R. Isolation and characterization of ACC deaminase genes from two different plant growth-promoting rhizobacteria. Can. J. Microbiol. 1998, 44, 833-843. [CrossRef]

23. Glick, B.R. Modulation of plant ethylene levels by the bacterial enzyme ACC deaminase. FEMS Microbiol. Lett. 2005, 251, 1-7. [CrossRef] [PubMed] 
24. Danish, S.; Zafar-Ul-Hye, M.; Hussain, S.; Riaz, M.; Qayyum, M.F. Mitigation of drought stress in maize through inoculation with drought tolerant ACC deaminase containing PGPR under axenic conditions. Pak. J. Bot. 2020, 52, 49-60. [CrossRef]

25. Danish, S.; Zafar-ul-Hye, M.; Mohsin, F.; Id, M.H. ACC-deaminase producing plant growth promoting rhizobacteria and biochar mitigate adverse effects of drought stress on maize growth. PLOS ONE 2020, 15, e230615. [CrossRef] [PubMed]

26. Honma, M.; Shimomura, T. Metabolism of 1-aminocyclopropane-1-carboxylic acid. Agric. Biol. Chem. 1978, 42, 1825-1831. [CrossRef]

27. Glick, B.R. Bacterial ACC deaminase and the alleviation of plant stress. Adv. Appl. Microbiol. 2004, 56, 291-312. [CrossRef]

28. Spokas, K.A.; Baker, J.M.; Reicosky, D.C. Ethylene: Potential key for biochar amendment impacts. Plant Soil 2010, 333, 443-452. [CrossRef]

29. Marris, E. Putting the carbon back: Black is the new green. Nature 2006, 442, 624-626. [CrossRef]

30. Lehmann, J.; Gaunt, J.; Rondon, M. Bio-char sequestration in terrestrial ecosystems-A review. Mitig. Adapt. Strateg. Glob. Chang. 2006, 11, 395-419. [CrossRef]

31. Lehmann, J. Bio-energy in the black. Front. Ecol. Environ. 2007, 5, 381-387. [CrossRef]

32. Glaser, B.; Haumaier, L.; Guggenberger, G.; Zech, W. The "Terra Preta" phenomenon: A model for sustainable agriculture in the humid tropics. Naturwissenschaften 2001, 88, 37-41. [CrossRef]

33. Steiner, C.; Glaser, B.; Teixeira, W.G.; Lehmann, J.; Blum, W.E.H.; Zech, W. Nitrogen retention and plant uptake on a highly \weathered central Amazonian Ferralsol amended \with compost and charcoal. J. Plant Nutr. Soil Sci. 2008, 171, 893-899.

34. Tian, J.; Wang, J.; Dippold, M.; Gao, Y.; Blagodatskaya, E.; Kuzyakov, Y. Biochar affects soil organic matter cycling and microbial functions but does not alter microbial community structure in a paddy soil. Sci. Total Environ. 2016, 556, 89-97. [CrossRef] [PubMed]

35. Zafar-ul-Hye, M.; Tahzeeb-ul-Hassan, M.; Abid, M.; Fahad, S.; Brtnicky, M.; Dokulilova, T.; Datta, R.; Danish, S. Potential role of compost mixed biochar with rhizobacteria in mitigating lead toxicity in spinach. Sci. Rep. 2010, 10, 12159. [CrossRef]

36. Iqbal, H.; Garcia-Perez, M.; Flury, M. Effect of biochar on leaching of organic carbon, nitrogen, and phosphorus from compost in bioretention systems. Sci. Total Environ. 2015, 521-522, 37-45. [CrossRef]

37. Ippolito, J.A.; Laird, D.A.; Busscher, W.J. Environmental benefits of biochar. J. Environ. Qual. 2012, 41, 967-972. [CrossRef] [PubMed]

38. Chen, Y.; Shinogi, Y.; Taira, M. Influence of biochar use on sugarcane growth, soil parameters, and groundwater quality. Aust. J. Soil Res. 2010, 48, 526-530. [CrossRef]

39. Yu, O.-Y.; Raichle, B.; Sink, S. Impact of biochar on the water holding capacity of loamy sand soil. Int. J. Energy Environ. Eng. 2013, 4, 44. [CrossRef]

40. Fiaz, K.; Danish, S.; Younis, U.; Malik, S.A.; Raza Shah, M.H.; Niaz, S. Drought impact on Pb/Cd toxicity remediated by biochar in Brassica campestris. J. Soil Sci. Plant Nutr. 2014, 14, 845-854. [CrossRef]

41. Keshavarz, A.R.; Hashemi, M.; DaCosta, M.; Spargo, J.; Sadeghpour, A. Biochar application and drought stress effects on physiological characteristics of silybum marianum. Commun. Soil Sci. Plant Anal. 2016, 47, 743-752. [CrossRef]

42. Shafie, S.T.; Mohd, M.A.; Hang, L.L.; Azlina, W.; Abdul, W.; Ghani, K. Effect of pyrolysis temperature on the biochar nutrient and water retention capacity. J. Purity Util. React. Environ. 2012, 1, 323-337.

43. Naz, I.; Rehim, A.; Zafar-ul-Hye, M.; Zahir, Z.A.; Abid, M.; Ali, M.A.; Hussain, M. Effectiveness of ACC-deaminase containing Pseudomonas strains to induce salinity tolerance in maize under fertilized and unfertilized field conditions. Soil Environ. 2013, 32, 167-172.

44. Stearns, J.C.; Woody, O.Z.; McConkey, B.J.; Glick, B.R. Effects of bacterial ACC deaminase on Brassica napus gene expression. Mol. Plant-Microbe Interact. 2012, 25, 668-676. [CrossRef] [PubMed]

45. Zafar-ul-Hye, M.; Zahir, Z.A.; Shahzad, S.M.; Naveed, M.; Arshad, M.; Khalid, M. Preliminary screening of rhizobacteria containing ACC-deaminase for promoting growth of lentil seedlings under axenic condition. Pak. J. Bot. 2007, 39, 1725-1738.

46. Zahir, Z.A.; Zafar-ul-Hye, M.; Sajjad, S.; Naveed, M. Comparative effectiveness of Pseudomonas and Serratia sp. containing ACC-deaminase for coinoculation with Rhizobium leguminosarum to improve growth, nodulation, and yield of lentil. Biol. Fertil. Soils 2011, 47, 457-465. [CrossRef] 
47. Danish, S.; Younis, U.; Akhtar, N.; Ameer, A.; Ijaz, M.; Nasreen, S.; Huma, F.; Sharif, S.; Ehsanullah, M. Phosphorus solubilizing bacteria and rice straw biochar consequence on maize pigments synthesis. Int. J. Biosci. 2015, 5, 31-39. [CrossRef]

48. Abid, M.; Danish, S.; Zafar-ul-Hye, M.; Shaaban, M.; Iqbal, M.M.; Rehim, A.; Qayyum, M.F.; Naqqash, M.N. Biochar increased photosynthetic and accessory pigments in tomato (Solanum lycopersicum L.) plants by reducing cadmium concentration under various irrigation waters. Environ. Sci. Pollut. Res. 2017, 24, 22111-22118. [CrossRef]

49. Qayyum, M.F.; Abid, M.; Danish, S.; Saeed, M.K.; Ali, M.A. Effects of various biochars on seed germination and carbon mineralization in an alkaline soil. Pak. J. Agric. Sci. 2014, 51, 977-982.

50. Younis, U.; Danish, S.; Shah, M.H.R.; Malik, S.A. Nutrient shifts modeling in Spinacea oleracea L. and Trigonella corniculata L. in contaminated soil amended with biochar. Int. J. Biosci. 2014, 5, 89-98. [CrossRef]

51. Dworkin, M.; Foster, J.W. Experiments with some microorganisms which utilize ethane and hydrogen. J. Bacteriol. 1958, 75, 592-603. [CrossRef]

52. El-Tarabily, K.A. Promotion of tomato (Lycopersicon esculentum Mill.) plant growth by rhizosphere competent 1-aminocyclopropane-1-carboxylic acid deaminase-producing streptomycete actinomycetes. Plant Soil 2008, 308, 161-174. [CrossRef]

53. Glickmann, E.; Dessaux, Y. A critical examination of the specificity of the Salkowski reagent for indolic compounds produced by phytopathogenic bacteria. Appl. Environ. Microbiol. 1995, 61, 793-796. [CrossRef] [PubMed]

54. Vazquez, P.; Holguin, G.; Puente, M.E.; Lopez-Cortes, A.; Bashan, Y. Phosphate-solubilizing microorganisms associated with the rhizosphere of mangroves in a semiarid coastal lagoon. Biol. Fertil. Soils 2000, 30, 460-468. [CrossRef]

55. Setiawati, T.C.; Mutmainnah, L. Solubilization of potassium containing mineral by microorganisms from sugarcane rhizosphere. Ital. Oral Surg. 2016, 9, 108-117. [CrossRef]

56. Chapman, H.D.; Pratt, P.F. Methods of Analysis for Soils, Plants and Water; University of California, Division of Agricultural Sciences: Berkeley, CA, USA, 1961.

57. Jones, J.B.; WolfH, B.; Mills, H.A. Plant Analysis Handbook: A Practical Sampling, Preparation, Analysis, and Interpretation Guide; Micro-Macro Publishing Inc.: Athens, GA, USA, 1991.

58. Nadeem, F.; Ahmad, R.; Rehmani, M.I.A.; Ali, A.; Ahmad, M.; Iqbal, J. Qualitative and chemical analysis of rice kernel to time of application of phosphorus in combination with zinc under anaerobic conditions. Asian J. Agric. Biol. 2013, 1, 67-75.

59. Van Schouwenberg, J.C.; Walinge, I. Methods of Analysis for Plant Material; Agricultural University Wageningen: Wageningen, The Netherlands, 1973.

60. Qayyum, M.F.; Steffens, D.; Reisenauer, H.P.; Schubert, S. Kinetics of carbon mineralization of biochars compared with wheat straw in three soils. J. Environ. Qual. 2012, 41, 1210. [CrossRef] [PubMed]

61. Noor, N.M.; Shariff, A.; Abdullah, N. Slow pyrolysis of cassava wastes for biochar production and characterization. Iran. J. Energy Environ. 2012, 3, 60-65.

62. Datta, R.; Vranová, V.; Pavelka, M.; Rejsek, K.; Formánek, P. Effect of soil sieving on respiration induced by low-molecular-weight substrates. Int. Agrophysics 2014, 28. [CrossRef]

63. Gee, G.W.; Bauder, J.W. Particle-size analysis. In Methods of Soil Analysis. Part 1. Physical and Mineralogical Methods; American Society of Agronomy: Madison, WI, USA, 1986; pp. 383-411, ISBN 978-0-89118-864-3.

64. Walkley, A. An examination of methods for determining organic carbon and nitrogen in soils. J. Agric. Sci. 1935, 25, 598. [CrossRef]

65. Olsen, S.R.; Sommers, L.E. Phosphorus. In Method of Soil Analysis, Agron. No. 9, Part 2: Chemical and Microbiological Properties; Page, A.L., Ed.; American Society of Agronomy: Madison, WI, USA, 1982; pp. 403-430.

66. Marfo, T.D.; Datta, R.; Pathan, S.I.; Vranová, V. Ecotone Dynamics and Stability from Soil Scientific Point of View. Diversity 2019, 11, 53. [CrossRef]

67. Danso Marfo, T.; Datta, R.; Vranová, V.; Ekielski, A. Dynamics and Stability from Soil Perspective: Forest-Agriculture Land Transition. Agriculture 2019, 9, 228. [CrossRef]

68. Yadav, G.S.; Datta, R.; Imran Pathan, S.; Lal, R.; Meena, R.S.; Babu, S.; Das, A.; Bhowmik, S.; Datta, M.; Saha, P. Effects of conservation tillage and nutrient management practices on soil fertility and productivity of rice (Oryza sativa L.)-rice system in north eastern region of India. Sustainability 2017, 9, 1816. [CrossRef] 
69. Ahmad, I.; Akhtar, M.J.; Zahir, Z.A.; Naveed, M.; Mitter, B.; Sessitsch, A. Cadmium-tolerant bacteria induce metal stress tolerance in cereals. Environ. Sci. Pollut. Res. 2014, 21, 11054-11065. [CrossRef]

70. Ahmad, M.T.; Asghar, N.; Saleem, M.; Khan, M.Y.; Zahir, Z.A. Synergistic effect of rhizobia and biochar on growth and physiology of maize. Agron. J. 2015, 107, 2327-2334. [CrossRef]

71. Nadeem, S.M.; Zahir, Z.A.; Naveed, M.; Arshad, M. Rhizobacteria containing ACC-deaminase confer salt tolerance in maize grown on salt-affected fields. Can. J. Microbiol. 2009, 55, 1302-1309. [CrossRef] [PubMed]

72. Shaharoona, B.; Arshad, M.; Zahir, Z.A. Effect of plant growth promoting rhizobacteria containing ACC-deaminase on maize (Zea mays L.) growth under axenic conditions and on nodulation in mung bean (Vigna radiata L.). Lett. Appl. Microbiol. 2006, 42, 155-159. [CrossRef] [PubMed]

73. Zafar-ul-Hye, M.; Farooq, M.H.; Hussain, M. Bacteria in combination with fertilizers promote root and shoot growth of maize in saline-sodic soil. Braz. J. Microbiol. 2015, 46, 97-102.

74. GOP. Wheat Production Technology. Available online: http://dai.agripunjab.gov.pk/croptechnologies (accessed on 17 May 2017).

75. Nazar, R.; Khan, M.I.R.; Iqbal, N.; Masood, A.; Khan, N.A. Involvement of ethylene in reversal of salt-inhibited photosynthesis by sulfur in mustard. Physiol. Plant. 2014, 152, 331-344.

76. Arnon, D.I. Copper Enzymes in Isolated Chloroplasts. Polyphenoloxidase in Beta vulgaris. Plant Physiol. 1949, 24, 1-15. [CrossRef]

77. Lutts, S.; Kinet, J.M.; Bouharmont, J. NaCl-induced senescence in leaves of rice (Oryza sativa L.) cultivars differing in salinity resistance. Ann. Bot. 1996, 78, 389-398. [CrossRef]

78. Steel, R.G.; Torrie, J.H.; Dickey, D.A. Principles and Procedures of Statistics: A Biometrical Approach, 3rd ed.; McGraw Hill Book International Co.: Singapore, 1997.

79. Mayak, S.; Tirosh, T.; Glick, B.R. Plant growth-promoting bacteria confer resistance in tomato plants to salt stress. Plant Physiol. Biochem. 2004, 42, 565-572. [CrossRef]

80. Glick, B.; Penrose, D.; Li, J. A model for the lowering of plant ethylene concentrations by plant growth-promoting bacteria. J. Theor. Biol. 1998, 190, 63-68. [CrossRef] [PubMed]

81. Glick, B.R.; Patten, C.L.; Holguin, G.; Penrose, D.M. Biochemical and Genetic Mechanisms Used by Plant Growth Promoting Bacteria; Imperial College Press: London, UK, 1999.

82. Novak, J.M.; Lima, I.; Gaskin, J.W.; Steiner, C.; Das, K.C.; Ahmedna, M.; Watts, D.W.; Warren, J.; Schomberg, H. Characterization of designer biochar produced at different temperatures and their effects on a loamy sand. Ann. Environ. Sci. 2009, 3, 195-206.

83. Lehmann, J.; Rillig, M.C.; Thies, J.; Masiello, C.A.; Hockaday, W.C.; Crowley, D. Biochar effects on soil biota-A review. Soil Biol. Biochem. 2011, 43, 1812-1836. [CrossRef]

84. Danish, S.; Ameer, A.; Qureshi, T.I.; Younis, U.; Manzoor, H.; Shakeel, A.; Ehsanullah, M. Influence of biochar on growth and photosynthetic attributes of Triticum aestivum L. under half and full irrigation. Int. J. Biosci. 2014, 5, 101-108. [CrossRef]

85. Drogue, B.; Combes-Meynet, E.; Moënne-Loccoz, Y.; Wisniewski-Dyé, F.; Prigent-Combaret, C. Control of the cooperation between plant growth-promoting rhizobacteria and crops by rhizosphere signals. In Molecular Microbial Ecology of the Rhizosphere; de Bruijn, F.J., Ed.; Wiley-Blackwell: Hoboken, NJ, USA, 2013; Volume 1, pp. 279-293. ISBN 9781118296172.

86. Shukla, K.P.; Sharma, S.; Singh, N.K.; Singh, V.; Tiwari, K. Nature and role of root exudates: Efficacy in bioremediation. Afr. J. Biotechnol. 2011, 10, 9717-9724. [CrossRef]

87. Lojkova, L.; Vranová, V.; Formánek, P.; Drápelová, I.; Brtnicky, M.; Datta, R. Enantiomers of Carbohydrates and Their Role in Ecosystem Interactions: A Review. Symmetry 2020, 12, 470.

88. Nadeem, S.M.; Imran, M.; Naveed, M.; Khan, M.Y.; Ahmad, M.; Zahir, Z.A.; Crowley, D.E. Synergistic use of biochar, compost and plant growth-promoting rhizobacteria for enhancing cucumber growth under water deficit conditions. J. Sci. Food Agric. 2017, 97, 5139-5145. [CrossRef]

89. Matile, P.; Schellenberg, M.; Vicentini, F. Planta Localization of chlorophyllase in the chloroplast envelope. Planta 1997, 201, 96-99. [CrossRef]

90. Zheng, Z.; Parent, L.E.; MacLeod, J.A. Influence of soil texture on fertilizer and soil phosphorus transformations in Gleysolic soils. Can. J. Soil Sci. 2003, 83, 395-403. [CrossRef]

91. Borch, K.; Bouma, T.J.; Lynch, J.P.; Brown, K.M. Ethylene: A regulator of root architectural responses to soil phosphorus availability. Plant Cell Environ. 1999, 22, 425-431. [CrossRef] 
92. Younis, U.; Shah, M.H.R.; Danish, S.; Malik, S.A.; Ameer, A. Biochar role in improving biometric and growth attributes of S. oleracea and T. corniculata under cadmium stress. Int. J. Biosci. 2014, 5, 84-90.

93. Richardson, A.E.; Hocking, P.J.; Simpson, R.J.; George, T.S. Plant mechanisms to optimise access to soil phosphorus. Crop Pasture Sci. 2009, 60, 124-143. [CrossRef]

94. Chan, K.Y.; Van Zwieten, L.; Meszaros, I.; Downie, A.; Joseph, S. Using poultry litter biochars as soil amendments. Aust. J. Soil Res. 2008, 46, 437-444. [CrossRef]

(C) 2020 by the authors. Licensee MDPI, Basel, Switzerland. This article is an open access article distributed under the terms and conditions of the Creative Commons Attribution (CC BY) license (http://creativecommons.org/licenses/by/4.0/). 